\title{
EXPLORING CRITICAL SUCCESS FACTORS FOR STAKEHOLDER MANAGEMENT IN CONSTRUCTION PROJECTS
}

\author{
Jing Yang ${ }^{1}$, Geoffrey Qiping Shen ${ }^{2 *}$, Manfong $\mathrm{Ho}^{3}$, Derek S. Drew ${ }^{4}$, and Albert P. C. Chan ${ }^{5}$ \\ Dept of Building and Real Estate, The Hong Kong Polytechnic Univ., Hong Kong \\ E-mails: ${ }^{1} 06902079 r @ p o l y u . e d u . h k ;{ }^{2 *}$ Corresponding author: bsqpshen@polyu.edu.hk; \\ 33scrysta@polyu.edu.hk; ${ }^{4} d e r e k s d r e w @ h o t m a i l . c o m ;{ }^{5}$ bsachan@polyu.edu.hk \\ Received 05 Feb 2009; accepted 23 Sept 2009
}

\begin{abstract}
With a focus on different aspects of stakeholder management, various sets of critical success factors (CSFs) have been suggested in the literature. It is crucial to explore the relative importance and groupings of these factors. This paper aims to identify CSFs associated with stakeholder management in construction projects, and explore their ranking and underlying relationship. 15 CSFs were identified through a literature review, and consolidated by interviews and pilot studies with professionals in construction industry. A questionnaire instrument containing these 15 CSFs was sent out to project managers in Hong Kong, and 183 completed questionnaires were retrieved. The top three ranked factors for stakeholder management were "managing stakeholders with social responsibilities", "assessing the stakeholders' needs and constraints to the project", and "communicating with stakeholders properly and frequently". Using factor analysis and considering the high importance of the factor "managing stakeholders with social responsibilities", the 15 CSFs were grouped into five dimensions namely, precondition factor, stakeholder estimation, information inputs, decision making, and sustainable support. All these five groupings and their relationship were included in a framework for successful stakeholder management in construction projects. These findings help to clarify what the high prioritized factors are, and could also be used as an assessment tool to evaluate the performance of stakeholder management and thus help to identify areas for improvement.
\end{abstract}

Keywords: critical success factors (CSFs), stakeholder management, construction projects, rankings and groupings, Hong Kong.

\section{Introduction}

An increasing number of studies (Newcombe 2003; Olander and Landin 2005; El-Gohary et al. 2006) have identified the importance of stakeholder management in construction projects. However, the construction industry has a poor record of stakeholder management during the past decades (Loosemore 2006) owing to the complexity and uncertainty of projects. Many problems of stakeholder management in construction projects proposed by previous scholars include inadequate engagement of stakeholders, project managers having unclear objectives of stakeholder management, difficulty to identify the "invisible" stakeholder, and inadequate communication with stakeholders (Pouloudi and Whitley 1997; Loosemore 2006; Bourne and Walker 2006; Rowlinson and Cheung 2008). In order to solve these problems, project teams need to know what the essentials are for managing stakeholders (Cleland and Ireland 2002).

To identifying the essentials of stakeholder management, Critical Success Factors (CSFs) approach is used in this study. This approach was first developed by Rockart (1979). CSFs can be defined as "areas, in which results, if they are satisfactory, will ensure successful competitive performance for the organisation" (Rockart 1979). Saraph et al. (1989), viewed them as "those criti- cal areas of managerial planning and action that must be practised in order to achieve effectiveness". Many researchers (e.g. Chan et al. 2001; Jefferies et al. 2002; Yu et al. 2006) have used this method as a means to improve the performance of the management process. In the field of stakeholder management, Cleland and Ireland (2002) consider important that the project team should know whether or not it is successfully "managing" the project stakeholders. In this paper, CSFs are viewed as those activities and practices that should be addressed in order to ensure effective management of stakeholders.

The review of the literature suggested that there are numerous CSFs that can be identified as being crucial to the successful implementation of stakeholder management. Jergeas et al. (2000) identified 2 aspects of improvements for managing stakeholders, which are: "communication with stakeholders and setting common goals, objectives and project priorities". Landin (2000) considers "the longterm performance of any construction and its ability to satisfy stakeholders" depends on decisions made and the care taken by decision-makers in stakeholder communication. Aaltonen et al. (2008) state that the key issue in project stakeholder management is managing the relationship between the project and its stakeholders. These proposed factors may be the critical successful factors for stakeholder management in construction projects, but most of these 


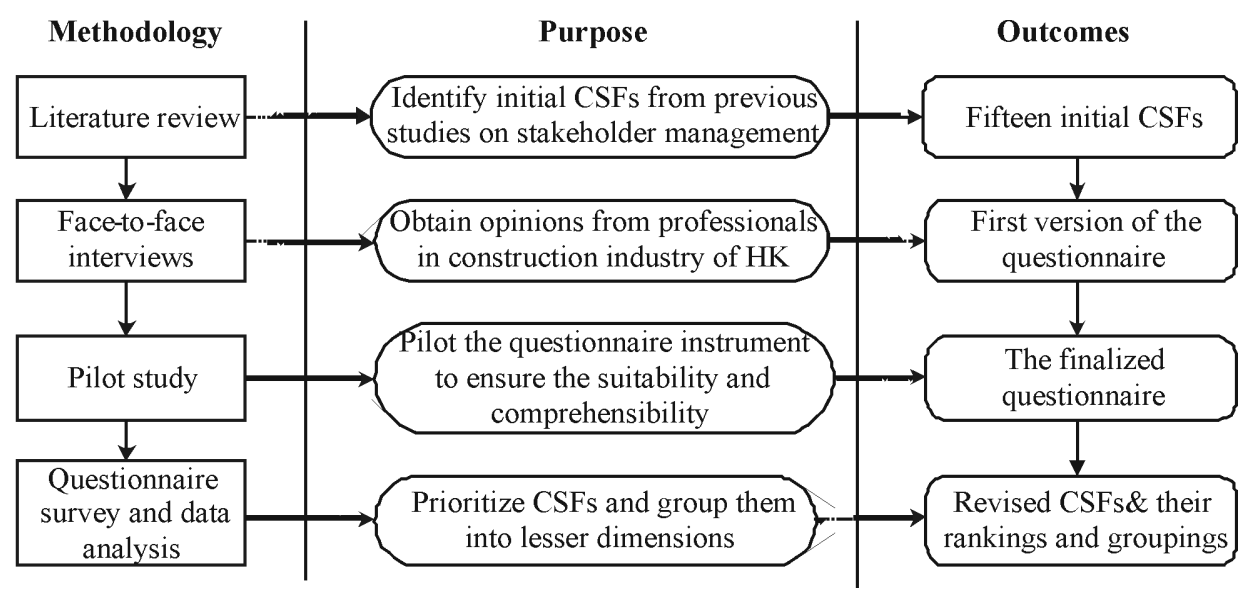

Fig. 1. Research framework of this study

studies are descriptive reviews, lack detailed quantitative analysis and fail to prioritize the relative importance of those success factors. In addition, as suggested by Aksorn and Hadikusumo (2008), these factors need to be grouped so that "few and essential CSFs representing a wide variety of issues can be revealed".

In this regard, it is crucial to explore the relative importance and groupings of factors that are significantly important for stakeholder management in construction projects. Therefore, this paper aims to identify and quantitatively prioritize CSFs associated with stakeholder management in construction projects of Hong Kong, and group the factors into lesser dimensions by using factor analysis.

\section{Research methodology}

The specific methodology of this study is based on a literature review, 6 face-to-face interviews, a pilot study and a questionnaire survey (Fig. 1). The research flow follows the procedure in the studies of Walker (1997) and Chan et al. (2004).

\section{An overview of CSFs for stakeholder management}

Factors contributing to the success of stakeholder management in construction projects are first identified by previous studies on this subject. Eight top journals (Construction Management and Economics, Journal of Construction Engineering and Management, Engineering Construction and Architectural Management, Journal of Management in Engineering, International Journal of Project Management, Automation in Construction, Project Management Journal and Building Research and Information) and 4 search engines (Google Scholar, ABI database, EI CompendexWeb, and ISI web of knowledge) were searched by using the keywords of "stakeholder", "project participants", or "project environment". These different sources were tried with the aim of finding the publications about stakeholder management in construction sector as complete as possible, and make a comprehensive review on the captioned topic. The first selection of publications was from abstracts if they were available, and the second selection made after reading the specific documents. In total, 68 publications with respect to stakeholder issues in construction sector remained for analysis at last. The publications consist of journals papers, international conference papers, theses, booklets, reports and some chapters in 8 books.

These publications were reviewed to derive CSFs for stakeholder management in construction projects theoretically. CSFs can also be identified from studies on stakeholder management in general or "the works of those who have addressed a particular factor in detail" (Wong and Aspinwall 2005). An in depth literature review indicated that numerous factors had been identified as important for stakeholder management. Although different terminologies were used in different studies to indicate factors, they can be represented by generic themes (Wong and Aspinwall 2005). Based on the literature review, 15 factors contributing to the success of stakeholder management in construction projects are hypothesized and proposed. These are as follows:

\section{Undertaking social responsibilities}

Wood, Gray (1991) believes the stakeholder theory is the theory most often associated with corporate social responsibility, as stakeholders are central to the very concept of corporate social performance. Carroll (1991) suggests, there is a natural fit between the ideas of corporate social responsibility and an organization stakeholders, as the stakeholder concept personalizes social responsibilities by delineating specific groups or persons that business should consider in its corporate social responsibility orientations and activities. Donaldson and Preston (1995) presented taxonomy of stakeholder theory types - normative, instrumental, and descriptive - and used the taxonomy to guide their discussion on the stakeholder literature. They suggest the central core to stakeholder theory is the normative approach, which implies that "organizations should acknowledge the validity of diverse stakeholder interests and should attempt to respond to them within a mutually supportive framework because it is a moral requirement". According to Carroll's definition (1979), social responsibility encompasses "the economic (the obligation to produce goods and services, sell them at fair prices and make a profit), legal (obligation to obey the law), and ethical (issues not embodied in law but expected by society) 
expectations that society has of organizations at a given point in time". Recently environmental expectation has also been paid a high attention by lots of scholars (e.g. AlWaer et al. 2008; Prager and Freese 2009) for sustainability reasons. The environmental consideration includes air, flora/fauna, dust, water, and noise, and the purpose is to protect environment. As discussed above, scholars have studied social responsibilities of stakeholder management from these 4 perspectives: economic (El-Sawah 2006), legal (Radin 2002; Crow 2008), environmental (AlWaer et al. 2008; Reed 2008; Prager and Freese 2009), and ethical (Phillips 2003; Moodley et al. 2008; Smyth 2008). Therefore, project managers should try to manage stakeholders with corporate social (economic, legal, environmental and ethical) responsibilities (Yang et al. 2008).

\section{Defining project missions}

The identification of a clear mission for the projects at different stages is widely considered to be essential for the effective management of stakeholders (Winch 2000). Before every activity of stakeholder management, the project manager should have a better understanding of the tasks and objectives at a particular stage of the project lifecycle, including the issues of cost, schedule, budget, etc. The complexity of client organizations and the social, economic, and regulatory environment in which the projects operate means that "the strategic definition of the project mission is inevitably politicized" (Winch 2000). Using interviews, Jergeas et al. (2000) proved further that "setting common goals, objectives and project priorities" is significant for improving stakeholder management.

\section{Identifying stakeholders}

Most of scholars studying stakeholder management (Karlsen 2002; Olander 2006; Walker et al. 2008; Jepsen and Eskerod 2008) have pointed out the significant importance of identifying stakeholders. Though the project stakeholders can be divided into different types according to various criteria (Pinto 1998), the question of "who are stakeholders?" (Frooman 1999) should be answered first before classifying and managing stakeholders.

\section{Understanding the area of stakeholders' interests}

There are various stakeholders' interests due to the complex nature of construction projects (Cleland 1999). Freeman et al. (2007) believe that identifying stakeholder interests is an important task to assess stakeholders, and they listed stakeholders' interests including product safety, integrity of financial reporting new product services, and financial returns. Similarly, Karlsen (2002) also presents one possible consideration to evaluate stakeholders "his or her area of interests in the project".

\section{Exploring stakeholders' needs and constraints in projects}

Exploring stakeholders' needs and constraints in projects means to anatomize stakeholders' area of interests and list the detailed issues stakeholders' concerns (Freeman et al. 2007). During the project process, all stakeholders' needs should be assessed "so that a satisfactory and realistic solution to the problem being addressed is obtained" (Love et al. 2004). Homoplastically, Kocak (2003) clarifies that stakeholders' needs can provide an indication of the stakeholder groups' concerns, the problems the project team faces, and stakeholders' requirements of the projects. Further more, Olander and Landin (2008) also proved the importance of "analysis of stakeholder concerns and needs" by case studies in Sweden.

\section{Assessing stakeholders' behaviour}

The capacity and willingness of stakeholders to threaten or cooperate with project teams should be measured (Savage et al. 1991) during stakeholder management process. Stakeholders' behaviour can be sorted into 3 categories: observed behaviour, cooperative potential, and competitive threat (Freeman 1984). Freeman et al. (2007) state that project managers need to clearly understand the range of stakeholder reactions and behaviours. By studying a pulp mill construction project in Uruguay, Aaltonen et al. (2008) identified 8 different stakeholders' behaviours/strategies employed to shape salience attributes. This study further demonstrates the significance of assessing stakeholders' behaviours.

\section{Predicting the influence of stakeholders}

Project management procedure is affected by project stakeholders (Olander 2007). Therefore recognizing the stakeholders' influence is important to "plan and execute a sufficiently rigorous stakeholder management process" (Olander and Landin 2005). Olander (2007) developed the "stakeholder impact index", and he considers that analyzing the potential impact of stakeholders indicates to determine the nature and impact of stakeholder influence, the probability of stakeholders exercising their influence and each stakeholder's position in relation to the project.

\section{Assessing attributes of stakeholders}

The attributes of stakeholders need to be assessed by project teams properly (Mitchell et al. 1997; Bourne 2005). Mitchell et al. (1997) proposed 3 attributes in their study, namely, power, urgency, and legitimacy. Power means the ability to "control resources, create dependencies, and support the interests of some organization members or groups over others" (Mitchell et al. 1997). Bourne and Walker (2005) believe that successful project managers should have the ability to understand the "invisible power" among stakeholders. Urgency is "the degree to which stakeholder claims call for immediate attention" (Mitchell et al. 1997). Legitimacy is "a generalized perception or assumption that the actions of an entity are desirable, proper, or appropriate within some socially constructed system of norms, values, beliefs, and definitions" (Suchman 1995). Bourne (2005) considers the proximity as an important attribute of stakeholders, which can be rated from "directly working in the project" to "remote from the project". Analyzing and estimating these 3 attributes enhance the understanding of project managers on stakeholders. 


\section{Analyzing conflicts and coalitions among stakeholders}

Conflict occurs whenever disagreements exist in a social situation (Schermerhorn et al. 2003). Analyzing the conflicts and coalitions among stakeholders is an important step for stakeholder management (Freeman 1984). Types of conflict include "substantive conflict and emotional conflict" (Schermerhorn et al. 2003). Project managers should know the potential conflicts stemming from divergent interests (Frooman 1999). Project managers should also search for possible coalitions among stakeholders. This concept comes from Freeman's strategy model (Freeman 1984). He believes the groups, who share objectives, stakeholders or interests about the project, can be more likely to form coalitions.

\section{Compromising conflicts}

Since there are various conflicts among stakeholders, compromising these conflicts become important for project managers to make decisions (Freeman 1984). A positive relationship between conflict resolution and satisfaction of stakeholders has been confirmed by Leung et al. (2005) with a questionnaire survey. How to make a "multi-win" compromise solution is a problem faced by project teams (Bana e Costa et al. 2001).

\section{Promoting a good relationship}

Successful relationships between the project and its stakeholders are vital for successful delivery of projects and meeting stakeholder expectations (Cleland 1986; Savage et al. 1991; Jergeas et al. 2000; Hartmann 2002). Trust and commitment among stakeholders can be built and maintained by an efficient relationships management (Pinto 1998; Bourne 2005; Karlsen et al. 2008).

\section{Formulating appropriate strategies}

Schwager (2004) points out that the central question of stakeholder management was "what are the strategies that organizations use to address stakeholders?". Similar result is obtained by Karlsen (2002) from a survey; he stated that there are different types of the strategies, but basically the stakeholder management strategy is the attitude how the project management team treats different stakeholders. In order to identify different kinds of strategies which are enacted by organizations as responses to the demands presented by external stakeholders, through an empirical analysis of 4 different projects, Aaltonen and Sivonen (2009) explained the use and emergence of the "response strategies". All these scholars have proved the importance of formulating appropriate strategies to deal with stakeholders.

\section{Predicting stakeholders' reactions}

'Stakeholders' reactions to the strategies' is an important factor when project managers make decisions about strategies to deal with stakeholders (Freeman et al. 2007). Attention to stakeholder response is also paid by Dias (1999). By applying fuzzy set method, he emphasized his studies on the feasibility and acceptability of strategies for stakeholders. Therefore, a project team should proceed to predict stakeholder behaviour in implementing strategy (Cleland and Ireland 2002).

\section{Analyzing the change of stakeholders}

The concepts of the change and dynamics of stakeholders were acknowledged by Freeman (1984). According to him, in reality stakeholders and their influence change over time, and this depends on the strategic issue under consideration. Dynamics of stakeholder is a very interesting and important aspect of the stakeholder concept (Elias et al. 2002). The uncertainty caused by stakeholders includes "who the stakeholders are", the influence of them, their needs, and the implications of relationships among stakeholders (Ward and Chapman 2008).

\section{Ensuring effective communication}

Communication is essential for maintaining the support and commitment of all stakeholders (Briner et al. 1996). Effective, regular, and planned communication with all members of the project community is necessary for project success (Briner et al. 1996; Cleland 1995). In addition, Weaver (2007) believes project managers should be highly skilled negotiators and communicators capable of managing individual stakeholder's expectations and creating a positive culture change within the overall organization.

\section{Interviews and pilot study}

Since the 15 CSFs were identified in the literature review, they should be further confirmed by professionals of construction industry before developing the questionnaire instrument. The preliminary list of CSFs was presented to 6 industrial experts during face-to-face interviews. These experts were selected because they all had more than 10 years overall experience in stakeholder management of construction projects, and they played different roles in projects and on different levels of position (Table 1). The interviews were conducted in the interviewees' office, and lasted for 0.5 to 1 hour, depending on the interviewees' available time slots and how many comments they gave. All interviewees agreed that the proposed 15 factors were critical and comprehensive, and meanwhile some interviewees provided valuable comments on the scope and language of factor statement. For example, the first factor was changed from "Undertaking social responsibilities" to a more detailed description "Managing stakeholders with social responsibilities (economic, legal, environmental and ethical)"; the last factor was changed from "Ensuring effective communication" to "Communicating with and engaging stakeholders properly and frequently", since the interviewees thought "engaging stakeholders" should be emphasised. Another important comment is that regarding the attributes of stakeholders, the interviewees thought that the attribute of legitimacy is imprecise and difficult to operationalize, and they all preferred using the attribute "proximity", which is easier to explain. Considering this comment, and also since the definition of legitimacy is more related with the "norma- 
tive core" for stakeholder theory (Mitchell et al. 1997), which has been considered in the factor about social responsibilities, legitimacy is not included as stakeholders' attributes. These comments were significant for questionnaire development since they promoted description of the factors for better comprehension. The first version of the questionnaire was developed after these interviews.

Table 1. Expert profiles

\begin{tabular}{c|l|l|c}
\hline Expert & $\begin{array}{l}\text { Role in } \\
\text { projects }\end{array}$ & \multicolumn{1}{|c}{ Position } & $\begin{array}{c}\text { Experience } \\
\text { (years) }\end{array}$ \\
\hline 1 & Client & Chief project manager & 21 \\
\hline 2 & Client & Senior project manager & 15 \\
\hline 3 & Consultant & Site project manager & 12 \\
\hline 4 & Client & Site project manager & 15 \\
\hline 5 & Contractor & Senior project manager & 13 \\
\hline 6 & Contractor & Site project manager & 11 \\
\hline
\end{tabular}

Prior to sending to questionnaires, a pilot study was conducted. Two project managers, one is client representative and the other is a contractor, were prompted to answer the preliminary questionnaire. The aim of the pilot study was to pre-test the suitability and comprehensibility of the questionnaire. There were no adverse comments proposed, so the finalized questionnaire is the same as that of the first version. The statements of the 15 CSFs are as follows:

C1. Managing stakeholders with social responsibilities (economic, legal, environmental and ethical);

C2. Formulating a clear statement of project missions;

C3. Identifying stakeholders properly;

C4. Understanding area of stakeholders' interests;

C5. Exploring stakeholders' needs and constraints to projects;

C6. Assessing stakeholders' behaviour;

C7. Predicting the influence of stakeholders accurately;

C8. Assessing attributes (power, urgency, and proximity) of stakeholders;

C9. Analyzing conflicts and coalitions among stakeholders;

C10. Compromising conflicts among stakeholders effectively;

C11. Keeping and promoting good relationships;

$\mathrm{C} 12$. Formulating appropriate strategies to manage stakeholders;

C13. Predicting stakeholders' reactions for implementing the strategies;

C14. Analyzing the change of stakeholders' influence and relationships during the project process;

C15. Communicating with and engaging stakeholders properly and frequently.

\section{Design and administration of the questionnaire survey}

The questionnaire comprises 4 sections: background information of the respondents; opinions of respondents on stakeholder management; key issues about stakeholder management; comments about the questionnaire. Although the questionnaire survey dealt with various issues relating to stakeholder management in construction projects, this paper only presents the analysis results of the relative importance and groupings of the identified 15 CSFs.

The questionnaire survey was undertaken in Hong Kong in August 2008, and the target of this survey was project managers from different organizations in the construction industry. The information about project managers, including their name, phone, email and mail address, was collected randomly from the Internet, newspapers, magazines, the membership lists of 2 institutes (the Association for Project Management Hong Kong, and the Hong Kong Construction Association), and the register lists published by the Buildings Department of Hong Kong. 654 questionnaires were delivered to the potential respondents by mail and email. Respondents were requested to rate their degree of agreement against each of the identified CSFs according to a five-point Likert scale ( $1=$ Strongly Disagree and $5=$ Strongly Agree $)$ with reference to a particular project they had been involved in. About 3 weeks were given to the respondents to complete and return it. The ways for retrieving it include mail, email and fax. 183 completed questionnaires were received consisting of 81 respondents from client organizations, 45 from contractors companies, and 57 from consultant organizations. The response rate was $28 \%$, which was consistent with "the norm of $20-30 \%$ with most questionnaire surveys in the construction industry" (Akintoye 2000).

\section{Data analysis and key findings}

The obtained raw data were inputted and analysed with the aid of the Statistical Package for Social Sciences (SPSS) computer software. Three types of analysis were conducted. These methods had been used by other similar survey studies carried out by Akintoye (2000), Chan et al. (2004), Wong and Aspinwall (2005), and Aksorn and Hadikusumo (2008). According to Pallant (2001), only when the parametric assumptions (normal distribution and homogeneity of variance) are fulfilled, the matched parametric testing methods can be employed. Since those assumptions are not fulfilled in this survey, the parametric methods were not used. The process of data analysis is as follows.

First, the relative importance of the $15 \mathrm{CSFs}$ was explored based on responses. This type of scale has been found to be acceptable in several construction management researches (e.g. Wang et al. 1999; Chan et al. 2003; Li et al. 2005). Kendall's Coefficient of Concordance was calculated for measuring the agreement of respondents on their rankings of CSFs. The Spearman's rank correlation test was used to examine the general similarity on the rankings of CSFs between respondents from client, contractor and consultant companies.

Second, a factor analysis was used to determine the underlying relationships among the 15 CSFs. The principal component analysis for factor extraction was applied to categorize the CSFs into a fewer number of groupings.

Third, since Wong and Aspinwall (2005) have pointed out that validating and refining the CSFs is important for data analysis, reliability and validity tests of the raw data were conducted depending on the overall data and results of factor analysis. 


\subsection{Ranking of CSFs}

The analysis of the survey response data produced the means for the 15 CSFs ranging from 3.80 to 4.43 , which indicated that all respondents consider these 15 factors critical for stakeholder management in construction projects. Ranking and Kendall's coefficient of concordance for the CSFs are shown in Table 2. The highest ranking by all respondents was "managing stakeholders with social responsibilities (economic, legal, environmental and ethical)" (mean $=4.43$ ), which therefore was considered as an extremely influential factor to the success of stakeholder management. "Exploring stakeholders' needs and constraints to projects" and "communicating with and engaging stakeholders properly and frequently" (mean $=4.26)$ were both ranked as the second most influential factors. The 4th ranked factor was "understanding area of stakeholders' interests" (mean $=4.22)$, whereas the 5th ranked factor was "identifying stakeholders properly" (mean value $=4.21$ ); the 6th factor was "keeping and promoting a good relationship" (mean value $=4.17$ ). These 6 factors were the top six CSFs for stakeholder management in construction projects of Hong Kong. In addition, it is worth noting, that all respondents perceived "predicting stakeholders' reactions for implementing the strategies", "analyzing the change of stakeholders' influence and relationships during the project process" and "assessing stakeholders' behaviour" as the 3 least influential factors.

In order to examine whether the respondents ranked the $15 \mathrm{CSF}$ in a similar order, Kendall's coefficient of concordance was calculated. According to Yeung et al. (2007), if the concordance coefficient is equal to 1 , it means that all the respondents rank the CSFs identically; in contrast, if the concordance coefficient is equal to 0 , it means that all the respondents rank the CSFs totally differently. The Kendall's coefficient of concordance for ran- king the 15 CSFs in Table 2 was 0.122 , which was statistically significant at $1 \%$ level. This suggested that there was a general agreement among 183 respondents on ranking the 15 CSFs; that is, the respondents shared similar values about the relative importance of these $15 \mathrm{CSFs}$. In order to examine the general similarity on the rankings of CSFs between respondents from client, contractor and consultant companies, the Spearman's rank correlation test was used to show whether or not the similarities are significant (Singh and Tiong 2006). The results of this test were interpreted by correlation coefficients (r). The value of these coefficients indicates the strength of the correlation between 2 variables. If $r$ is significant at $5 \%$ level, this means the 2 variables have a strong correlation. Table 3 shows the correlation coefficients (r) of different pairs of respondents, i.e. $r$ is 0.624 between respondents from client and contractor companies. These statistical results indicate a general consensus on the rankings of the CSFs among different groups of respondents; therefore, no matter the respondents from client, contractor or consultant companies, they rank the 15 CSFs similarly in general.

\subsection{Factor analysis of the CSFs}

Norusis (1992) and Li et al. (2005) state that "factor analysis is used to identify a relatively small number of factor groupings that can be used to represent relationships among sets of many inter-related variables". In this survey, this method was used to determine the groupings of the 15 CSFs.

According to Pallant (2001), 2 main issues have to be considered in determining whether a data set is suitable for factor analysis: sample size and the strength of the relationship among the factors. In terms of sample size, Nunnalyy (1978) recommends a 10 to 1 ratio; that is, " 10 cases for each item to be factor analysed". The minimum number for

Table 2. Ranking of the 15 CSFs

\begin{tabular}{ll|c|c}
\hline & \multicolumn{1}{c|}{ CSFs } & Mean & Rank \\
\hline C1. & Managing stakeholders with social responsibilities (economic, legal, environmental and ethical) & 4.43 & 1 \\
C5. & Exploring stakeholders' needs and constraints to projects & 4.26 & 2 \\
C15. & Communicating with and engaging stakeholders properly and frequently & 4.26 & 2 \\
C4. & Understanding the area of stakeholders' interests & 4.22 & 4 \\
C3. & Identifying stakeholders properly & 4.21 & 5 \\
C11. & Keeping and promoting a good relationship & 4.17 & 6 \\
C9. & Analyzing conflicts and coalitions among stakeholders & 4.04 & 7 \\
C7. & Predicting the influence of stakeholders accurately & 4.02 & 8 \\
C12. & Formulating appropriate strategies to manage stakeholders & 3.97 & 9 \\
C8. & Assessing attributes (power, urgency, and proximity) of stakeholders & 3.91 & 10 \\
C10. & Compromising conflicts among stakeholders effectively & 3.88 & 11 \\
C2. & Formulating a clear statement of project missions & 3.87 & 12 \\
C13. & Predicting stakeholders' reactions for implementing the strategies & 3.83 & 13 \\
C14. & Analyzing the change of stakeholders' influence and relationships during the project process & 3.83 & 13 \\
C6. & Assessing stakeholders' behaviour & 3.80 & 15 \\
\hline
\end{tabular}

Notes: Number $=183$.

Kendall's coefficient of concordance $=0.122$. Level of significance: 0.00 .

For 'Mean scores': 1 = least important and $5=$ most important. 
Table 3. Spearman rank correlation coefficients

\begin{tabular}{c|c|c|c}
\hline Respondents & $\begin{array}{c}\text { Client / } \\
\text { Contractor }\end{array}$ & $\begin{array}{c}\text { Client / } \\
\text { Consultant }\end{array}$ & $\begin{array}{c}\text { Contractor / } \\
\text { Consultant }\end{array}$ \\
\hline $\mathrm{r}$ & $.624^{*}$ & $.893^{*}$ & $.803^{*}$ \\
\hline
\end{tabular}

*Correlation is significant at 0.05 level (2-tailed).

factor analysis suggested by Pallant (2001) is 150. There were 15 factors in this survey, so according to Nunnalyys' recommendation (1978), 150 respondents should be obtained. Actually 183 respondents have been obtained in this study. The number was larger than 150 . Therefore, the sample size was enough for factor analysis. In terms of the strength of relationship among the factors, the correlation matrix (Tabachnik and Fidell 1996), the Bartlett's test of sphericity (Bartlett 1954), and the Kaiser-MeyerOlkin (KMO) (Kaiser 1970) were recommended. Most values in the correlation matrix are larger than 0.3 , the Bartlett's test of sphericity is significant $(p<0.05)$, and the value of the KMO index is above 0.6 , suggesting the data set is suitable for factor analysis. In this survey, more than a half of the correlation coefficients (Table 4) were above 0.3 , the Bartlett's test of sphericity was significant $(p<0.05)$ (Table 5), and the value of the KMO index was 0.870 (above 0.6) (Table 5). The results of these tests confirmed that the data were appropriate for factor analysis.

A 4-component solution was produced based on Varimax rotation of principal component analysis (Table 6). These 4 factor groupings with eigenvalues greater than 1.000 explain $61.532 \%$ of the variance. Each of the CSFs belonged to only one of the groupings, with the value of factor loading exceeding 0.50 (Norusis 1992; Li et al. 2005; Aksorn and Hadikusumo 2008). It was noticed that C1 "Managing stakeholders with social responsibilities (economic, legal, environmental and ethical)" do not belong to any of the factor groupings. The residual 14 CSFs can be grouped into 4 principal components, and the corresponding importance ranking of the extracted components was: (1) stakeholder estimation, (2) information inputs, (3) decision-making, and (4) sustainable support.

\section{Component 1: stakeholder estimation}

This component, which accounted for $37.44 \%$ (Table 6) of the total variances between critical success factors, was relatively more important than the other 3 components. It indicated that project managers in Hong Kong consider estimating stakeholders significant for stakeholder management in construction projects. To enhance the understanding of project managers on stakeholders, their attributes, behaviour, and potential influence need to be assessed and estimated. The conflicts and coalitions among stakeholders also could be analysed based on the information about stakeholders. Therefore, this component, which relates to estimate stakeholders, could be illustrated by $\mathrm{C} 8, \mathrm{C} 6, \mathrm{C} 7$, and $\mathrm{C} 9$.

\section{Component 2: information inputs}

This component ranked second among the 4 components (Table 6). Four CSFs comprise the elements of this component regarding information input. Before any management activities, comprehensive information about the project and stakeholders around it needs to be obtained. The information includes project missions, full list of stakeholders, area of stakeholders' interests, and their needs and constraints to the project. The stakeholders could be managed depending on these inputs.

Table 4. The correlation matrix of the CSFs

\begin{tabular}{c|c|c|c|c|c|c|c|c|c|c|c|c|c|c|c}
\hline CSFs & C1 & C2 & C3 & C4 & C5 & C6 & C7 & C8 & C9 & C10 & C11 & C12 & C13 & C14 & C15 \\
\hline C1 & 1.00 & .245 & .266 & .331 & .322 & .115 & .265 & .243 & .217 & .243 & .357 & .322 & .313 & .248 & .266 \\
\hline $\mathrm{C} 2$ & .245 & 1.00 & .420 & .352 & .274 & .153 & .210 & .063 & .220 & .331 & .307 & .314 & .240 & .192 & .105 \\
\hline $\mathrm{C} 3$ & .266 & .420 & 1.00 & .489 & .406 & .307 & .316 & .255 & .270 & .300 & .302 & .373 & .427 & .327 & .192 \\
\hline $\mathrm{C} 4$ & .331 & .352 & .489 & 1.00 & .586 & .408 & .412 & .324 & .413 & .248 & .331 & .357 & .302 & .390 & .279 \\
\hline $\mathrm{C} 5$ & .322 & .274 & .406 & .586 & 1.00 & .280 & .365 & .256 & .414 & .194 & .396 & .257 & .229 & .358 & .354 \\
\hline $\mathrm{C} 6$ & .115 & .153 & .307 & .408 & .280 & 1.00 & .534 & .430 & .410 & .286 & .323 & .262 & .292 & .429 & .232 \\
\hline $\mathrm{C} 7$ & .265 & .210 & .316 & .412 & .365 & .534 & 1.00 & .545 & .463 & .433 & .365 & .377 & .487 & .437 & .217 \\
\hline $\mathrm{C} 8$ & .243 & .063 & .255 & .324 & .256 & .430 & .545 & 1.00 & .419 & .254 & .292 & .219 & .329 & .298 & .076 \\
\hline $\mathrm{C} 9$ & .217 & .220 & .270 & .413 & .414 & .410 & .463 & .419 & 1.00 & .358 & .270 & .306 & .320 & .520 & .237 \\
\hline $\mathrm{C} 10$ & .243 & .331 & .300 & .248 & .194 & .286 & .433 & .254 & .358 & 1.00 & .347 & .416 & .471 & .276 & .160 \\
\hline $\mathrm{C} 11$ & .357 & .307 & .302 & .331 & .396 & .323 & .365 & .292 & .270 & .347 & 1.00 & .459 & .339 & .345 & .347 \\
\hline $\mathrm{C} 12$ & .322 & .314 & .373 & .357 & .257 & .262 & .377 & .219 & .306 & .416 & .459 & 1.00 & .512 & .471 & .411 \\
\hline $\mathrm{C} 13$ & .313 & .240 & .427 & .302 & .229 & .292 & .487 & .329 & .320 & .471 & .339 & .512 & 1.00 & .489 & .125 \\
\hline $\mathrm{C} 14$ & .248 & .192 & .327 & .390 & .358 & .429 & .437 & .298 & .520 & .276 & .345 & .471 & .489 & 1.00 & .414 \\
\hline $\mathrm{C} 15$ & .266 & .105 & .192 & .279 & .354 & .232 & .217 & .076 & .237 & .160 & .347 & .411 & .125 & .414 & 1.00 \\
\hline
\end{tabular}

Table 5. Bartlett's test for the CSFs and KMO

\begin{tabular}{l|l|r}
\hline \multirow{3}{*}{ Bartlett's test of sphericity } & Approx. Chi-Square & 960.363 \\
\cline { 2 - 3 } & df & 105 \\
\cline { 2 - 3 } & Sig. & .000 \\
\hline \multicolumn{2}{|c|}{ Kaiser-Meyer-Olkin measure of sampling adequacy } & .870 \\
\hline
\end{tabular}


Table 6. Results of factor analysis

\begin{tabular}{|c|c|c|c|c|c|}
\hline Components & Eigenvalue & $\%$ of variance & Name of components ${ }^{\mathrm{a}}$ & $\mathrm{CSFs}^{\mathrm{b}}$ & Factor loading \\
\hline \multirow[t]{4}{*}{1} & \multirow[t]{4}{*}{5.618} & \multirow[t]{4}{*}{37.455} & \multirow[t]{4}{*}{ Stakeholder estimation } & $\mathrm{C} 8$ & .760 \\
\hline & & & & C6 & .727 \\
\hline & & & & $\mathrm{C} 7$ & .713 \\
\hline & & & & C9 & .649 \\
\hline \multirow[t]{4}{*}{2} & \multirow[t]{4}{*}{1.347} & \multirow[t]{4}{*}{8.978} & \multirow[t]{4}{*}{ Information inputs } & $\mathrm{C} 2$ & .713 \\
\hline & & & & $\mathrm{C} 3$ & .676 \\
\hline & & & & $\mathrm{C} 4$ & .678 \\
\hline & & & & $\mathrm{C5}$ & .636 \\
\hline \multirow[t]{3}{*}{3} & \multirow[t]{3}{*}{1.181} & \multirow[t]{3}{*}{7.872} & \multirow[t]{3}{*}{ Decision-making } & $\mathrm{C} 13$ & .727 \\
\hline & & & & $\mathrm{C} 10$ & .713 \\
\hline & & & & C12 & .617 \\
\hline \multirow[t]{3}{*}{4} & \multirow[t]{3}{*}{1.084} & \multirow[t]{3}{*}{7.227} & \multirow[t]{3}{*}{ Sustainable support } & $\mathrm{C} 15$ & .873 \\
\hline & & & & $\mathrm{C} 14$ & .535 \\
\hline & & & & C11 & .501 \\
\hline
\end{tabular}

\section{Component 3: Decision-making}

Three CSFs were included in this component relating to decision-making. Project managers have the responsibility to compromise conflicts among stakeholders, and formulate appropriate strategies to manage stakeholders. During the process of decision-making, project managers always try to predict the reaction of stakeholders and choose the optimal solution for managing stakeholders.

\section{Component 4: Sustainable support}

Though this component ranked least among the 4 components (Table 6), it is indispensable for stakeholder management. The reason is that if the first 3 components could be considered as factors regarding one management process, this fourth component is related to the sustainability of stakeholder management. Construction projects are transient (Bourne 2005), but organizations are correspondingly permanent. Since many stakeholders, such as government, local communities and media, would be involved at later stages of the project process or in future projects, project managers, as the representatives of different organizations, have the responsibility to realize the change of their influence and relationships, promote a steady relationship with them, and communicate with them properly and frequently.

\subsection{Validation of the CSFs}

Testing for reliability of a scale Cronbach's Coefficient Alpha was used to examine internal consistency of the scales under the headings of the CSFs. Alpha values greater than 0.7 are regarded as sufficient (Pallant 2001). The results of Cronbach's Coefficient Alpha in this survey were in the range of 0.8625 to 0.8763 . This provides evidence that all the factors have a high internal consistency and are reliable.

Testing for content validity

Ahire et al. (1996) believe that if the measurement items in the survey "adequately cover the content domains or aspects of the concept being measured", an instrument has content validity. Gotzamani and Tsiotras (2001), Wong and Aspinwall (2005) also have clarified that "it is not assessed numerically, but can only be subjectively judged by the researchers". As discussed in Section 3, the CSFs listed in this survey were identified by a comprehensive review of relevant literature and validated by several interviews and pilot studies with the professionals in the construction industry. Therefore, it was believed that the whole questionnaire has valid contents.

Testing for construct validity

Construct validity was used to check for unifactoriality (Black and Porter 1996). Antony et al. (2002) clarified that "unifactoriality means that a single factor is extracted for each test". Each factor grouping was evaluated by factor analysis for construct validity. Table 7 presents results of the unifactorial test. Since all of the KMO value were greater than 0.5 , and the percentage of variance explained by each component was more than $56 \%$, all 4 components were demonstrated to be unifactorial.

Results of the 3 tests

Since all the factors have high internal consistency, the whole questionnaire has valid contents and all 4 components were demonstrated to be unifactorial, the CSFs developed in this study were both reliable and valid.

Table 7. Unifactorial test

\begin{tabular}{ccccc}
\hline Component & KMO value & Factor loading & Eigenvalue & Percentage variance explained \\
\hline 1 & 0.776 & $0.728-0.831$ & 2.405 & 60.132 \\
2 & 0.721 & $0.646-0.825$ & 2.275 & 56.880 \\
3 & 0.653 & $0.744-0.814$ & 1.817 & 60.556 \\
4 & 0.606 & $0.697-0.848$ & 1.789 & 59.622 \\
\hline
\end{tabular}




\section{Discussions of survey results}

The research findings indicate that $\mathrm{C} 1$ "Managing stakeholders with social responsibilities (economic, legal, environmental and ethical)" ranked first in the $15 \mathrm{CSF}$ for stakeholder management in construction projects. This means that project managers considered this factor as the most important one for the success of stakeholder management. As discussed in the overview (Section 3), this finding was in line with several researchers' statements (e.g. Wood 1991; Carroll 1991; and Donaldson and Preston 1995). However, according to the results of factor analysis, this factor could not be included in any of the 4 components. Owing to the significance of this factor, the authors name this factor as the "precondition factor" for stakeholder management; that is, stakeholder management should be conducted with social (economic, legal, environmental and ethical) responsibilities. Under this precondition, and including the 4 components extracted by factor analysis, a framework for successful stakeholder management in construction projects is proposed in Fig. 2.

The framework in Fig. 2, which presents 5 factors groupings, contributes to the success of stakeholder management and their relationships. The 5 factors groupings are the "Precondition factor" and the 4 components extracted by factor analysis, which are stakeholder estimation, information inputs, decision-making, and sustainable support. Since the factor about social responsibilities $(\mathrm{C} 1)$ is the precondition of any activities for managing stakeholders, it is put on the top of the other 4 groupings in Fig. 2. According to general management process, information should be inputted first during the process of stakeholder management, and then stakeholders could be estimated based on the information obtained. After accurately assessing stakeholders, decisions could be made. Sustainable support need to be conducted during the whole process of stakeholder management, because in order to promote the management process, project managers need to monitor the change of stakeholders' influence and relationships, try to keep a steady relationship with them, and most importantly communicate with them properly and frequently.

\section{Conclusions}

The importance of stakeholder management has been recognized by many scholars and professionals. With a focus on different aspects of stakeholder management, various sets of CSFs have been suggested in the literature. It is crucial to explore the relative importance and groupings of these factors. This paper presented a part results of a questionnaire survey, and aims to identify CSFs associated with stakeholder management in construction projects of Hong Kong, and explore their ranking and underlying relationship.

The main contribution of this study is identifying an ordered and grouped set of CSFs for stakeholder management in construction projects of Hong Kong. 15 CSFs were identified through a literature review, face-to-face interviews and pilot studies. Based on a questionnaire survey, the ranking of these CSFs were obtained. This helps clarify what the highly prioritized factors are. The top 3 factors were: (1) managing stakeholders with social responsibilities (economic, legal, environmental and ethical), (2) exploring the stakeholders' needs and constraints to the project, and (3) communicating with and engaging stakeholders properly and frequently. Using the factor analysis and considering the high importance of the factor "managing stakeholders with social responsibilities" the 15 CSFs were grouped into 5 dimensions: precondition, factor, stakeholder estimation, information inputs, decision-making, and sustainable support. All these 5 groupings and their relationship were included in a framework for successful stakeholder management in construction projects. These findings could also be used as an assessment tool to evaluate the performance of stakeholder management and thus help identify areas for improvement. Since the results in this paper are based on a questionnaire survey, the respondents may have different understandings about our statements, and this may bias the scoring of the CSFs. Therefore, the findings in this paper should be further validated by case studies, of which the details will be presented in a new article. In addition, since the interviews and questionnaire survey were conducted locally in Hong Kong, the findings may not be generalized to the other geographical locations.

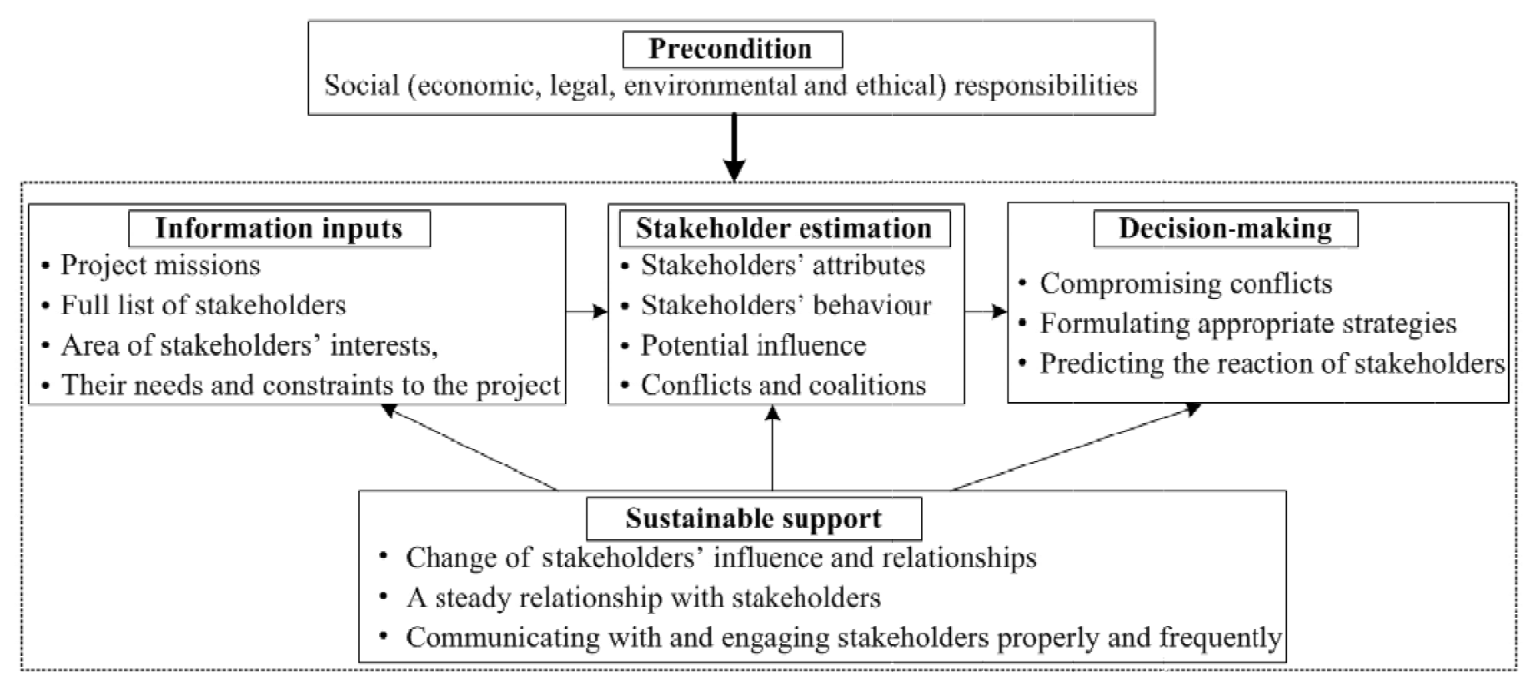

Fig. 2. A framework for successful stakeholder management in construction projects 
In future studies, the same research procedure should be conducted in other locations which have different cultures from Hong Kong to seek the similarities and differences of the CSFs for stakeholder management in construction projects.

\section{Acknowledgements}

The work described in this paper was supported by the Hong Kong Polytechnic University and the Research Grants Council of the Hong Kong Special Administrative Region, China (PolyU 52644/06E). Special gratitude is also extended to those industrial practitioners who have responded to and contributed their valuable input in completing the questionnaire.

\section{References}

Aaltonen, K.; Jaakko, K.; Tuomas, O. 2008. Stakeholder salience in global projects, International Journal of Project Management 26: 509-516. doi:10.1016/j.ijproman.2008.05.004

Aaltonen, K.; Sivonen, R. 2009. Response strategies to stakeholder pressures in global projects, International Journal of Project Management 27: 131-141. doi:10.1016/j.ijproman.2008.09.007

Ahire, S. L.; Golhar, D. Y.; Walker, M. A. 1996. Development and validation of TQM implementation constructs, Decision Sciences 27(1): 23-56. doi:10.1111/j.1540-5915.1996.tb00842.x

Akintoye, A. 2000. Analysis of factors influencing project cost estimating practice, Construction Management and Economics 18: 77-89. doi:10.1080/014461900370979

Aksorn, T.; Hadikusumo, B. H. W. 2008. Critical success factors influencing safety program performance in Thai construction projects, Safety Science 46: 709-727. doi:10.1016/j.ssci.2007.06.006

AlWaer, H.; Sibley, M.; Lewis, J. 2008. Different stakeholder perceptions of sustainability assessment, Architectural Science Review 57(1): 48-59.

Antony, J.; Leung, K.; Knowles, G.; Gosh, S. 2002. Critical success factors of TQM implementation in Hong Kong industries, International Journal of Quality \& Reliability Management 19(5): 551-566. doi:10.1108/02656710210427520

Bana e Costa, C. A.; Nunes da Silva, F.; Vansnick, J. C. 2001. Conflict dissolution in the public sector: A case-study, European Journal of Operational Research 130: 388401. doi:10.1016/S0377-2217(00)00037-0

Bartlett, M. S. 1954. A note on the multiplying factors for various chi square approximations, Journal of the Royal Statistical Society 16(Series B): 396-398.

Black, S. A.; Porter, L. J. 1996. Identification of the Critical Factors of TQM, Decision Sciences 27(1): 1-21. doi:10.1111/j.1540-5915.1996.tb00841.x

Bourne, L. 2005. Project Relationship Management and the Stakeholder CircleTM. PhD Thesis, RMIT University. Australia.

Bourne, L.; Walker, D. H. T. 2005. Visualising and mapping stakeholder influence, Management Decision 43(5): 649660. doi:10.1108/00251740510597680

Bourne, L.; Walker, D. H. T. 2006. Visualizing stakeholder influence - two Australian examples, Project Management Journal 37(1): 5-22.

Briner, W.; Hastings, C.; Geddes, M. 1996. Project Leadership. Aldershot, Gower.

Carroll, A. B. 1979. A three-dimensional conceptual model of corporate social performance, Academy of Management Review 4(4): 497-506. doi:10.2307/257850
Carroll, A. B. 1991. The pyramid of corporate social responsibility: Toward the moral management of organizational stakeholders, Business Horizons 7: 39-48. doi:10.1016/0007-6813(91)90005-G

Chan, P. C.; Chan, W. M.; Ho, S. K. 2003. An empirical study of the benefits of construction parting in Hong Kong, Construction Management and Economics 21: 523-533. doi:10.1080/0144619032000056162

Chan, P. C. A.; Chan, W. M. D.; Chiang, Y. H.; Tang, B. S.; Chan, H. W. E.; Ho, S. K. K. 2004. Exploring critical success factors for partnering in construction projects, Journal of Construction Engineering and Management March/April: 188-198. doi:10.1061/(ASCE)0733-9364(2004)130:2(188)

Chan, P. C. A.; Ho, C. K. D.; Tam, C. M. 2001. Design and build project success factors: multivariate analysis, Journal of Construction Engineering and Management March/April: 93-100. doi:10.1061/(ASCE)0733-9364(2001)127:2(93)

Cleland, D. I. 1986. Project stakeholder management, Project Management Journal 17(4): 36-44.

Cleland, D. I. 1995. Leadership and the project management body of knowledge, International Journal of Project Management 13(2): 82-88. doi:10.1016/0263-7863(94)00018-8

Cleland, D. I. 1999. Project Management Strategic Design and Implementation. McGraw-Hill, New York.

Cleland, D. I.; Ireland, R. L. 2002. Project Management: Strategic Design and Implementation. New York: McGraw-Hill.

Crow, D. A. 2008. Stakeholder behavior and legislative influence: A case study of recreational water rights in Colorado, The Social Science Journal Nov. (20): 1-13.

Dias, W. P. S. 1999. Soft systems approaches for analyzing proposed change and stakeholder response - a case study, Civil Engineering and Environmental Systems 17(1): 117. doi:10.1080/02630259908970271

Donaldson, T.; Preston, L. E. 1995. The stakeholder theory of the corporation: concepts, evidence, and implications, The Academy of Management Review 20(1): 65-88. doi: $10.2307 / 258887$

El-Gohary, N. M.; Osman, H.; Ei-Diraby, T. E. 2006. Stakeholder management for public private partnerships, International Journal of Project Management 24(7): 595-604. doi:10.1016/j.ijproman.2006.07.009

El-Sawah, H. M. 2006. Strategies for assessing and managing stakeholders in the Egyptian construction industry, Journal of Engineering and Applied Science 53(2): 195-213.

Elias, A. A.; Cavana, R. Y.; Jackson, L. S. 2002. Stakeholder analysis for $\mathrm{R} \& \mathrm{D}$ project management, $R \& D$ Management 34 (2): 301-310. doi:10.1111/1467-9310.00262

Freeman, E. 1984. Strategic Management: a Stakeholder Approach. Pitman Inc, Boston.

Freeman, R. E.; Harrison, J. S.; Wicks, A. C. 2007. Managing for Stakeholders - Survival, Reputation, and Success. Louis Stern Memorial Fund, US.

Frooman, J. 1999. Stakeholder influence strategies, Academy of Management Review 24(2): 191-205. doi:10.2307/259074

Gotzamani, K. D.; Tsiotras, G. D. 2001. An empirical study of the ISO 9000 standards' contribution towards total quality management, International Journal of Operations \& Production Management 21(10): 1326-1342. doi:10.1108/EUM0000000005972

Hartmann, F. T. 2002. The role of trust in project management, in Frontiers of Project Management Research. D. P. Slevin, D. I. Cleland and J. K.Pinto. Newtown Square, Pennsylvania, PMI, 225-235. 
Jefferies, M.; Gameson, R.; Rowlinson, S. 2002. Critical success factors of the BOOT procurement system: reflection from the Stadium Australia case study, Engineering, Construction and Architectural Management 9(4): 352361. doi:10.1046/j.1365-232X.2002.00249.x

Jepsen, A. L.; Eskerod, P. 2008. Stakeholder analysis in projects: Challenges in using current guidelines in the real world, International Journal of Project Management 4(2): 1-9.

Jergeas, G. F.; Williamson, E.; Skulmoski, G. J.; Thomas, J. L. 2000. Stakeholder management on construction projects, AACE International Transactions 12: 1-5.

Kaiser, H. 1970. A second generation little jiffy, Psychometrika 35: 401-415. doi:10.1007/BF02291817

Karlsen, J. T. 2002. Project stakeholder management, Engineering Management Journal 14(4): 19-24.

Karlsen, J. T.; Græe, K.; Massaoud, M. J. 2008. Building trust in project-stakeholder relationships, Baltic Journal of Management 3(1): 7. doi:10.1108/17465260810844239

Kocak, N. A. 2003. RUC Option Development Framework and Tools. PhD thesis. University of Westminster.

Landin, A. 2000. Impact of Quality Management in the Swedish Construction process. PhD thesis, Department of Construction Management, Lund University.

Leung, M. Y.; Liu, A. M. M.; Thomas, N. S. 2005. Is there a relationship between construction conflicts and participants' satisfaction?, Engineering, Construction and Architectural Management 12(2): 149-167. doi:10.1108/09699980510584494

Li, B.; Akintoye, A.; Edwards, P. J.; Hardcastle, C. 2005. Critical success factors for PPP/PFI projects in the UK construction industry, Construction Management and Economics 23: 459-471. doi:10.1080/01446190500041537

Loosemore, M. 2006. Managing project risks, in The Management of Complex Projects: A Relationship Approach, Pryke, S. and Smyth, H. Blackwell, UK.

Love, P. E. D.; Irani, Z.; Edwards, D. J. 2004. Industry-centric benchmarking of information technology benefits, costs, risks for small-to-medium sized enterprises in construction, Automation in Construction 13(4): 507-524. doi:10.1016/j.autcon.2004.02.002

Mitchell, R. K.; Agle, B. R.; Wood, D. J. 1997. Toward a theory of stakeholder identification and salience: defining the principle of who and what really counts, Academy of $\mathrm{Ma}$ nagement Review 22(4): 853-887. doi:10.2307/259247

Moodley, K.; Smith, N.; Preece, C. N. 2008. Stakeholder matrix for ethical relationships in the construction industry, Construction Management \& Economics 26(6): 625-632. doi:10.1080/01446190801965368

Newcombe, R. 2003. From client to project stakeholders: a stakeholder mapping approach, Construction Management and Economics 22(9/10): 762-784.

Norusis, M. J. 1992. SPSS for Windows, Professional Statistics, Release 5, SPSS Inc., Chicago.

Nunnally, J. O. 1978. Psychometric Theory. New York: McGraw-Hill.

Olander, S. 2006. External Stakeholder Management. PhD thesis, Lund University, UK.

Olander, S. 2007. Stakeholder impact analysis in construction project management, Construction Management and Economics 25(3): 277-287. doi:10.1080/01446190600879125

Olander, S.; Landin, A. 2005. Evaluation of stakeholder influence in the implementation of construction projects, In- ternational Journal of Project Management 23(4): 321. doi:10.1016/j.ijproman.2005.02.002

Olander, S., and Landin, A. 2008. A comparative study of factors affecting the external stakeholder management process, Construction Management and Economics 26(6): 553. doi:10.1080/01446190701821810

Pallant, J. 2001. SPSS Survival Manual. Open University Press, Buckingham and Philadephia.

Phillips, R. 2003. Stakeholder Theory and Organizational Ethics. Berrett-Koehler Publishers, US.

Pinto, J. K. 1998. Project Management Handbook. The Project Management Institute, Jossey-bass Inc., San Francisco, California, U.S.A.

Pouloudi, A.; Whitley, E. A. 1997. Stakeholder identification in inter-organizational systems: gaining insights for drug use, European Journal of Information System 6(1): 1. doi:10.1057/palgrave.ejis.3000252

Prager, K.; Freese, J. 2009. Stakeholder involvement in agrienvironmental policy making - Learning from a local and a state-level approach in Germany, Journal of Environmental Management 90(2): 1154-1167. doi:10.1016/j.jenvman.2008.05.005

Radin, T. J. 2002. From imagination to realization: A legal foundation for stakeholder theory, Research in Ethical Issues in Organizations 4: 31-49. doi:10.1016/S1529-2096(02)04004-X

Reed, M. S. 2008. Stakeholder participation for environmental management: A literature review, Biological Conservation 141(10): 2417-2431. doi:10.1016/j.biocon.2008.07.014

Rockart, J. F. 1979. Chief executives define their own data needs, Harvard Business Review 57(2): 81-93.

Rowlinson, S.; Cheung, Y. K. F. 2008. Stakeholder management through empowerment: modeling project success, Construction Management and Economics 26(6): 611. doi:10.1080/01446190802071182

Saraph, J. V.; Benson, P. G.; Schroeder, R. G. 1989. An instrument for measuring the critical factors of quality management, Decision Sciences 20(4): 810-29. doi:10.1111/j.1540-5915.1989.tb01421.x

Savage, G. T.; Nix, T. W.; Whitehead, C. J.; Blair, J. D. 1991. Strategies for assessing and managing organizational stakeholders, Academy of Management Executive 5(2): 61-75.

Schwager, H. P. 2004. Organizational strategies to address stakeholder relationships: A customer portal perspective. $\mathrm{PhD}$ thesis. Aubum University.

Schermerhorn, J. R.; Hunt, J. G.; Osborn, R. N. 2003. Organizational Behaviour, 8th edition. John Wiely \& Sons, Inc., USA.

Singh, D.; Tiong, R. L. K. 2006. Contractor selection sriteria: investigation of opinions of Singapore construction practitioners, Journal of Construction Engineering and Management 132(9): 998-1008. doi:10.1061/(ASCE)0733-9364(2006)132:9(998)

Smyth, H. 2008. The credibility gap in stakeholder management: ethics and evidence of relationship management, Construction Management and Economics 26(6): 611. doi:10.1080/01446190801905414

Suchman, M. C. 1995. Managing legitimacy: strategic and institutional approached, Academy of Management Review 20(3): 571-610. doi:10.2307/258788

Tabachnick, B. G.; Fidell, L. S. 1996. Using Multivariate Statistics. $3^{\text {rd }}$ edition. New York: HarperCollins. 
Walker, D. H. T. 1997. Choosing an appropriate research methodology, Construction Management and Economics 15(2): 149-159. doi:10.1080/01446199700000003

Walker, D. H. T.; Bourne, L. M.; Rowlinson, S. 2008. Stakeholder and The Supply Chain. Procurement Systems: A Cross-industry Project Management Perspective. Walker, D. H. T.; Rowlinson, S.; Taylor \& Francis.

Wang, S. Q.; Tiong, R. L. K.; Ting, S. K.; Ashley, D. 1999. Risk management framework for BOT power projects in China, Journal of Project Finance 4(4): 56-57.

Ward, S.; Chapman, C. 2008. Stakeholders and uncertainty management in projects, Construction Management and Economics 26(6): 563-577. doi:10.1080/01446190801998708

Weaver, P. 2007. Getting the "soft stuff" right-effective communication is the key to successful project outcomes! PMI Global Congress (North America). October 6-9, 2007.

Winch, G. 2000. Construction business systems in the European Union, Building Research and Information 28(2): 88.

Wong, K. Y.; Aspinwall, E. 2005. An empirical study of the important factors for knowledge-management adoption in the SME sector, Journal of Knowledge Management 9(3): 64-82. doi:10.1108/13673270510602773

Wood, D. J.; Gray, B. 1991. Toward a comprehensive theory of collaboration, Journal of Applied Behavioral Science 27(2): 139-162. doi:10.1177/0021886391272001

Yang, J.; Shen, Q. P.; Ho, M. F. 2008. A framework for stakeholder management in construction projects I: Theoretical foundation, International Conference on Construction and Real Estate Management 2008, 109-113.

Yeung, F. Y.; Chan, P. C.; Chan, W. M.; Li, L. K. 2007. Developing of a partnering performance index (PPI) for construction projects in Hong Kong: a Delphi study, Construction Management and Economics 25: 1219-1237. doi:10.1080/01446190701598673

Yu, T. W.; Shen, Q. P.; Kelly, J.; Hunter, K. 2006. Investigation of critical success factors in construction project briefing by way of content analysis, Journal of Construction Engineering and Management 132(11): 1178-1186. doi:10.1061/(ASCE)0733-9364(2006)132:11(1178)

\section{KRITINIŲ SĖKMĖS VEIKSNIŲ SUINTERESUOTŲJŲ ŠALIŲ VALDYMUI STATYBOS PROJEKTUOSE TYRIMAS}

\section{J. Yang, G. Q. Shen, M. Ho, D. S. Drew, A. P. C. Chan}

S a t r a u a

Atsižvelgiant i skirtingus suinteresuotųjų šalių valdymo aspektus, literatūroje siūlomi ịvairūs kritiniu sẻkmės veiksnių (KSV) kompleksai. Svarbiausia yra sugrupuoti šiuos veiksnius ir nustatyti jų santykinị reikšmingumą. Šio straipsnio tikslas - nustatyti KSV, susijusius su suinteresuotųų šalių valdymu statybos projektuose, išnagrinèti jų prioritetus ir pagrindinius tarpusavio ryšius. $15 \mathrm{KSV}$ buvo nustatyta remiantis literatūros analize, statybos šakos profesionalų apklausomis ir eksperimentinėmis studijomis. Projektų valdytojams Honkonge išsiųstas klausimynas ir gauti 183 atsakymai. Trys aukščiausiai įvertinti veiksniai: projektų dalyvių socialinė atsakomybė, suinteresuotujų šalių poreikių ir apribojimų įvertinimas, tinkamas ir dažnas bendradarbiavimas su suinteresuotomis šalimis. Naudojantis veiksnių analize ir atsižvelgiant į tai, kad socialinès atsakomybės rodiklis vertinamas kaip labai reikšmingas, $15 \mathrm{KSV}$ suskirstyti į 5 grupes: išankstinių veiksnių, suinteresuotujų grupių nustatymo, informacijos rinkimo, sprendimų prièmimo ir subalansuotos paramos. Visos šios grupės bei jų ryšiai buvo įtraukti į sistema, skirtą sẻkmingam suinteresuotųjų šalių valdymui statybos projektuose. Šie duomenys padeda paaiškinti, kokiems veiksniams suteikiamas prioritetas ir gali būti naudojami suinteresuotujų šalių valdymo igyvendinimui įvertinti bei tobulintinoms sritims nustatyti.

Reikšminiai žodžiai: kritiniai sẻkmės veiksniai (KSV), suinteresuotųjų šalių valdymas, statybos projektai, rangavimas ir grupavimas, Honkongas.

Ms. Jing YANG worked for the construction industry in the field of Quantity Surveying before switching to academia. Now she is a PhD student at the Department of Building and Real Estate, The Hong Kong Polytechnic University. Her research interests are in stakeholder management and social network analysis. She is also a committee member of the Hong Kong Institute of Value Management.

Professor Geoffrey Qi-Ping SHEN is an active researcher in group dynamics, value management, and partnering. He has led a large number of research projects with total funding over HK \$20 million including 7 successful RGC CERG, and published more than 100 papers in international refereed journals. He teaches extensively in these fields and has successfully supervised a number of PhD students. Professionally, he serves as the President of the Hong Kong Institute of Value Management; member of the Institute of Value Management (UK). As a certified value specialist (US) and value management facilitator (HK), he has professionally designed and facilitated a number of value management and/or partnering workshops for a variety of large projects.

Dr Christabel M. F. HO worked for the construction industry in the field of quantity surveying before switching to academia. She is a Chartered quantity surveyor and building engineer by profession. Member of both the Chartered Institute of Building and the Australian Institute of Building. Also a member of the Australian Institute of quantity surveyor. She completed her PhD at the University of New South Wales (Australia). Her current research interests include professional ethics and construction management.

Dr Derek S. DREW is an Associate Professor at the Department of Building and Real Estate, The Hong Kong Polytechnic University. His research interests include tendering, and competitiveness of contractors and consultants.

Professor Albert Ping-Chuen CHAN is a Professor and Associate Head at the Department of Building and Real Estate, The Hong Kong Polytechnic University. His research interests include project management and project success, project finance and public private partnerships, construction procurement and relational contracting, construction industry development and construction safety. 